\title{
Priamy a nepriamy predmet v slovenčine a španielčine
}

\author{
Mária SPIŠIAKOVÁ \\ Ekonomická univerzita, Bratislava \\ maria.spisiakova@euba.sk
}

Recibido: Mayo de 2014

Aceptado: Enero de 2014

\section{Resumé}

V článku sa analizujú ekvivalenty a rozdiely medzi priamym a nepriamym predmetom v španielčine a akuzatívom a datívom v slovenčine. Dalej sa autorka snaží nájst’ normy pre správne používanie zámen v datíve a akuzatíve v obidvoch jazykoch a sústredí sa na tretie osoby singuláru aj plurálu. Nakoniec sa vyvodia chyby a interferencie v používaní týchto zámen u slovensky hovoriacich.

Kl’účové slová: priamy a nepriamy predmet, akuzatív, datív, sloveso, španielčina, slovenčina.

\section{Resumen}

$$
\text { El complemento directo y el complemento indirecto en eslovaco y en español }
$$

El presente artículo analiza las equivalencias y diferencias entre el complemento directo e indirecto en español y el acusativo y dativo en eslovaco. A continuación intenta encontrar normas para el uso correcto de los pronombres de dativo y acusativo en los dos idiomas centrándose en el uso de los pronombres en las terceras personas del singular y plural. Al final deduce los errores e interferencias en el uso de estos pronombres en los hablantes eslovacos.

Palabras clave: complemento directo, complemento indirecto, acusativo, dativo, verbo, lengua española, lengua eslovaca.

\section{The direct and indirect object in Slovak and Spanish}

\begin{abstract}
This article analyzes the equivalences and differences between direct and indirect object in Spanish and accusative and dative in Slovak. The author tries to find rules for correct use of pronouns in dative and accusative in both languages, focusing on the use of pronouns in the third person singular and plural. At the end she deduces errors and interferences in the use of these pronouns by Slovak speakers.
\end{abstract}

Key words: direct object, indirect object, accusative, dative, verb, Spanish language, Slovak language. 


\section{Úvod}

Používanie zámen s akuzatívom a datívom (complemento directo a indirecto, d’alej $\mathrm{CD}, \mathrm{CI}$ ) predstavuje jeden z najčastejších problémov vyplývajúcich z interferencií (spolu s používaním minulých časov) medzi slovenčinou a španielčinou.

Aby sme mohli správne použit' osobné zámená CD alebo CI, musíme vediet' rozlíšit' medzi $C D$ a CI v španielčine. Ak správne identifikujeme $C D$ alebo CI vo vete, nemali by sme mat' problém použit' správne zámeno, pretože, ako d’alej uvidíme, pre CI sa použivajú iné zámená ako pre $\mathrm{CD}$.

Je treba ešte spomenút', že $\mathrm{v}$ španielčine sa pohybujeme na syntaktickej rovine, zatial' čo v slovenčine sa jedná o kategóriu gramatickú.

\section{Terminológia}

Skôr ako sa dostaneme k problematike používania zámen a rozlišovania $\mathrm{CD}$ a CI $\mathrm{v}$ španielčine, objasníme si terminológiu, ktorá sa tiež v určitých aspektoch rozlišuje, hoci ide o tú istú gramatickú kategóriu.

Vieme, že španielčina zdedila kategórie datívu a akuzatívu z latinčiny, ale $\mathrm{v}$ súčasnosti chápe túto kategóriu skôr ako syntaktickú a preto tiež používa pomenovanie priamy a nepriamy predmet $(\mathrm{CD}, \mathrm{CI})$. Hoci španielčina nie je flexívny jazyk, osobné zámená si ako jediný slovný druh skloňovanie zachovali a skloňujú sa práve $\mathrm{v}$ datíve a akuzatíve, hoci v gramatike sa používa syntaktická terminológia: pronombres de CD a CI (zámená priameho a nepriameho predmetu). Ide práve o používanie zámen $\mathrm{v}$ datíve a akuzatíve, pričom CI (nepriamy predmet) obyčajne korešponduje so slovenským datívom a CD (priamy predmet) so slovenským akuzatívom. Práve tu dochádza $\mathrm{k}$ interferenciám, pretože nie vždy sa všetky slovesá viažu rovnako v obidvoch jazykoch s datívom alebo akuzatívom.

\section{CD a CI sú v DRAE definované nasledovne:}

Complemento directo. El que está exigido por el verbo y completa su significación al designar la entidad a la que afecta directamente la acción verbal. Se construye sin preposición $\mathrm{o}$, en determinadas circunstancias, con la preposición a. [...] Puede sustituirse, y a veces coaparecer, con los pronombres átonos de acusativo, que en tercera persona adoptan las formas lo(s), la(s). (http://www.rae.es/diccionario-panhispanico-de-dudas/terminos-linguisticos) Preklad ${ }^{1}$ :

Priamy predmet. Viaže sa na sloveso a dopíňa jeho význam tým, že označuje predmet, ktorý je slovesným dejom priamo zasahovaný. Tvorí sa bez predložky alebo, v niektorých prípadoch, s predložkou a. [...] Môže sa nahradit', a niekedy aj spolu objavit' s neprízvučnými zámenami v akuzatíve, ktoré v tretej osobe nadobúdajú formy lo(s), la(s).

Complemento indirecto. Complemento del verbo que, si es un nombre o un grupo nominal, va precedido siempre de la preposición a y puede sustituirse o coaparecer con los pronombres átonos de dativo, que en tercera persona adoptan las formas le, les. Según el significado del verbo al que complementa, puede designar al destinatario de la acción:

\footnotetext{
1 Traducciones nuestras.
} 
le hablé de ti a mi jefe; al que resulta beneficiado o perjudicado por ella: te he limpiado la casa o le han roto la bicicleta a mi hermano; al que experimenta la noción que el verbo denota: le cuesta pedir disculpas; o a la persona o cosa afectadas positiva o negativamente por las características de algo: los pantalones le están grandes.

Preklad:

(http://www.rae.es/diccionario-panhispanico-de-dudas/terminos-linguisticos)

Nepriamy predmet. Rozvíjajúci vetný člen slovesa, ktorý je vždy sprevádzaný predložkou a, ak ide o meno alebo mennú konštrukciu. Môže sa nahradit' alebo spolu objavit' $\mathrm{s}$ neprízvučnými zámenami $\mathrm{v}$ datíve, ktoré majú $\mathrm{v}$ tretích osobách formu le, les. Podla významu slovesa, ktoré rozvijajú, môže vyjadrovat' príjemcu deja: hovoril som o tebe šéfovi; predmety, ktoré sú kladne alebo záporne dejom zasahované: poupratoval som $t i$ byt, môjmu bratovi zlomili bicykel; predmet, na ktorý sa dej priamo vztahuje: stoji ho to vel'a požiadat'o prepáčenie; alebo osoby a veci, ktoré sú zasiahnuté pozitívne alebo negatívne vlastnostami niečoho: nohavice sú mu vel'ké.

V Morfológii slovenského jazyka sa priamy a nepriamy predmet definuje nasledovne:

Priame predmety stoja po prechodných slovesách, t.j. po slovesách z intenčných typov Otec nesie drevo, Brata zabilo, a to samy (tzv. výlučné predmety), alebo v kombinácii s nepriamym prdmetom (tzv. združené premety). Priame predmety sa vyjadrujú prostým akuzatívom alebo syntakticky s ním rovnoznačnými inými pádmi, a to genitívom, napr. dat' chlapcom jablčka - dat' chlapcom jablícok, pri slovesách pohybu aj inštrumentálom, napr. hádzat'sebou, mykat' plecom. Okrajovo sa priamy predmet vyjadruje aj predložkovým pádom: genitívom s predložkou, napr. dat' (chlapcom) z jabľčok, lokálom s predložkou po, napr. dat' (chlapcom) po jablčku.

Nepriame predmety stoja jednak po prechodných slovesách ako druhá väzba, jednak pri slovesách z intenčného typu školník cengá, napr. grobianit' dakomu, gratulovat', papul'ovat'...dakomu, susedit's dakým/s dačim, sút'ažit', kontrastovat', kolidovat', hospodárit'/gazdovat's dačím. (BAJZÍKOVÁ 1984: 103-104)

Môžeme vidiet', že pády v slovenčine nehrajú rozhodujúcu úlohu pri určení, či ide o priamy a nepriamy predmet. To, $v$ akom páde je substantívum sa prejavuje na rozdelení predmetov podla sémantických a zároveň gramatických vlastností, kde rozoznávame podl'a Bajzíkovej pätoraké predmety: zásahový, výsledkový, ciel'ový (perspektívny), obsahový, vztahový. Napr.:

Zásahový predmet je vždy vyjadrený akuzatívom (štiepat’ drevo, prevážat tovar, farbit' obloky). $\mathrm{V}$ datíve bývajú predmety ciel'ové (vychovávat' $k$ dôslednosti, pohnút' $k$ l'útosti). (BAJZÍKOVÁ 1984: 104)

Z uvedeného môžeme vidiet', že nemôžeme nájst' presné ekvivalencie medzi priamym a nepriamym predmetom španielskym a slovenským.

Všimnime si teraz definície kategórie akuzatívu a datívu v španielčine:

Acusativo. En latín y otras lenguas, caso de la declinación en que se expresa el complemento directo, es decir, forma que en esas lenguas adoptan algunos elementos lingü- 
ísticos, como el nombre o el pronombre, para desempeñar dicha función. En español, esta denominación se refiere, generalmente, a los pronombres personales átonos de tercera persona $\mathrm{lo}(\mathrm{s}), \mathrm{la}(\mathrm{s})$, que proceden de formas latinas de acusativo. Preklad:

(http://www.rae.es/diccionario-panhispanico-de-dudas/terminos-linguisticos)

Akuzatív. Vlatinčine a v iných jazykoch, ohýbací pád, v ktorom sa vyjadruje priamy predmet, to znamená, forma, ktorú dostávajú v tých jazykoch určité jazykové jednotky, ako meno alebo zámeno, aby mohli plnit' spomínanú funkciu. V španielčine sa toto pomenovanie vzt’ahuje obyčajne na neprízvučné zámená v tretej osobe lo(s), la(s), ktoré pochádzajú z latinských foriem akuzatívu.

Dativo. En latín y otras lenguas, caso de la declinación en que se expresa el complemento indirecto, es decir, forma que en esas lenguas adoptan algunos elementos lingüísticos, como el nombre o el pronombre, para desempeñar dicha función. En español se aplica generalmente al pronombre personal átono de tercera persona le(s), que procede de una forma latina de dativo.

Preklad:

(http://www.rae.es/diccionario-panhispanico-de-dudas/terminos-linguisticos)

Datív. Vlatinčine a v iných jazykoch, ohýbací pád, v ktorom sa vyjadruje nepriamy predmet, to znamená, forma, ktorú dostávajú v tých jazykoch určité jazykové jednotky, ako meno alebo zámeno, aby mohli plnit' spomínanú funkciu. V španielčine sa toto pomenovanie aplikuje obyčajne na neprízvučné zámeno v tretej osobe le(s), ktoré pochádza z latinských foriem datívu.

Môžeme vidiet', že v španielskej terminológii zodpovedá akuzatív priamemu predmetu a datív nepriamemu predmetu.

Z tohto dôvodu budeme v našej práci používat' označenie datív a akuzatív, zámená $\mathrm{v}$ datíve a akuzatíve alebo predmet $\mathrm{v}$ datíve a akuzatíve, pretože, ako d'alej uvidíme, pôjde aj v slovenčine takmer výlučne (okrem niektorých výnimiek) o substantíva $\mathrm{v}$ datíve a akuzatíve.

\section{Zámená $\mathrm{v}$ datíve a akuzatíve}

Osobné zámená v datíve a akuzatíve v španielčine:
1. me
nos
2. te
os
3. le, la, lo, se
les, las, los
Zodpovedajú slovenským zámenám:
1. $m i, m a$
nám, nás
2. $t i, t^{\prime} a$
vám, vás
3. $m u$, jej, ho, ju
im, ich

V slovenčine je vyšší počet zámen, pretože, ako môžeme vidiet', v slovenčine rozoznávame datív a akuzatív vo všetkých osobách, zatial' čo v španielčine len v tretích. Preto sú to práve tretie osoby, ktoré spôsobujú problémy a pri ktorých dochádza k chybám v používaní španielskych zámen u slovensky hovoriacich. Vzhl'adom $\mathrm{k}$ tomu, že v 1. a 2. osobe tak singuláru ako aj plurálu používa španielčina tie isté 
zámená pre datív a akuzatív, slovensky hovoriaci s nimi nemá problém, ked’že nemusí rozlišovat', či ide $\mathrm{v}$ španielčine o priamy alebo nepriamy predmet:

Me explica. $(C I)=$ Vysvetluje mi. (dativo)

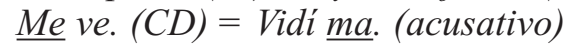

Pri rozlišovaní priameho a nepriameho predmetu $\mathrm{v}$ španielčine si môžeme pomôct' nasledujúcim pravidlom:

$\mathrm{CD}$ (priamy predmet) $\mathrm{v}$ španielčine $=$ akuzatív $\mathrm{v}$ slovenčine.

CI (nepriamy predmet) $\mathrm{v}$ španielčine $=$ datív $\mathrm{v}$ slovenčine.

Tu si však musíme uvedomit', že nie vždy toto pravidlo platí. V tretích osobách španielčina rozlišuje medzi datívom a akuzatívom a $\mathrm{v}$ prípade akuzatívu aj medzi mužským a ženským rodom aým a neživotným substantívom. Kvôli tomu sa stretávame s problémami pri používaní zámen v tretích osobách. Ďalším dôvodom je tiež trošku mätočné pravidlo $\mathrm{v}$ používaní le alebo lo $\mathrm{v}$ akuzatíve.

Mohli by sme vymedzit’ dva dôvody, kvôli ktorým dochádza k chybám v používaní osobných zámen v datíve a akuzatíve:

používanie le, lo, la $\mathrm{v}$ akuzatíve a iba zámena le $\mathrm{v}$ datíve.

nezhoda (interferencie) medzi CD (priamym predmetom) y CI (nepriamym predmetom) v španielčine $\mathrm{s}$ akuzatívom a datívom $\mathrm{v}$ slovenčine.

\section{Používanie osobných zámen v akuzatíve, „leísmo“"2}

V tejto časti sme sa sústredili na používanie zámen v akuzatíve, ked’že zámená $\mathrm{v}$ datíve nepredstavujú zmätok vzhl'adom $\mathrm{k}$ tomu, že sa nerozlišuje ani rod ani životnost' a použiva sa len zámeno $l e(s)$.

V akuzatíve sa stretávame s dvojznačnost'ou alebo s možnost'ou používat' zámeno le alebo lo pre mužské životné mená. Pýtame sa: Môžeme používat tieto zámená bez rozdielu alebo nie? Nesprávne používanie zámena le sa nazýva leísmo. Ale kedy $\mathrm{v}$ skutočnosti dochádza k leísmu pri životných mužských substantívach? Pozrime sa, čo hovoria španielske gramatiky:

1. Diccionario de la RAE, preguntas frecuentes (Slovník Španielskej královskej akadémie, časté otázky):

Para usar adecuadamente los pronombres átonos de $3{ }^{a}{ }^{a}$ persona $l o(s)$, la $(s)$, le(s) según la norma culta del español general, debe tenerse en cuenta, en primer lugar, la función sintáctica que desempeña el pronombre y, en segundo lugar, el género y el número gramatical de la palabra a la que se refiere. En el siguiente cuadro se muestra la distribución de formas y funciones de estos pronombres:

\begin{tabular}{|c|c|c|c|}
\hline & ersona & singular & plural \\
\hline \multirow{4}{*}{$\mathrm{CD}$} & masculino & lo & \\
\hline & & (también $\boldsymbol{l} \boldsymbol{e}$, cuando el referente es un hombre) & Los \\
\hline & femenino & la & Las \\
\hline & neutro & lo & - \\
\hline \multirow{2}{*}{\multicolumn{2}{|c|}{$\mathrm{CI}$}} & le & les \\
\hline & & \multicolumn{2}{|l|}{ (o se ante otro pron. átono) } \\
\hline
\end{tabular}

2 Nesprávne používanie zámena le. 
*En el Esbozo de una nueva gramática de la lengua española (RAE, 1973) se condena el leísmo referido a cosa, pero se permite el referido a persona masculina singular; el leísmo plural siempre ha sido censurado por la Academia, ya que su baja incidencia desde los textos castellanos más antiguos atestigua que tampoco lo ha sancionado nunca mayoritariamente el uso de los hablantes cultos.

A continuación se expone de forma sucinta la norma que rige el empleo de estos pronombres:

Cuando el pronombre desempeña la función de complemento directo, deben usarse las formas lo, los para el masculino (singular y plural, respectivamente) y la, las para el femenino (singular y plural, respectivamente):

¿Has visto a Juan? Sí, lo vi ayer.

¿Has visto a Juan y a los niños? Sí, los he visto en el parque.

Compré la medicina y se la di sin que nadie me viera.

¿Has recogido a las niñas? Sí, las recogi antes de ir al taller.

[Dada la gran extensión en el uso de los hablantes cultos de ciertas zonas de España de la forma le cuando el referente es un hombre, se admite, únicamente para el masculino singular, el uso de le en función de complemento directo de persona: ¿Has visto a Jorge? Si, le vi ayer en el parque.] (http://www.rae.es/consultas-linguisticas/preguntas-frecuentes)

Preklad:

Pre správne používanie neprízvučných zámen $\mathrm{v}$ tretích osobách $l o(s), l a(s)$, le(s) podl'a spisovnej normy je treba mat' na pamäti, na 1 . mieste syntaktickú funkciu zámena a na 2. mieste gramatický rod a čislo substantíva, ktoré nahrádza. V nasledujúcej tabul'ke vidíme formy a funkcie týchto zámen:

\begin{tabular}{|c|c|c|c|}
\hline 3. osoba & & Singulár & Plurál \\
\hline $\begin{array}{l}\text { CD } \\
\text { (priamy predmet) }\end{array}$ & $\begin{array}{l}\text { maskulínum } \\
\text { femenínum } \\
\text { neutrum }\end{array}$ & $\begin{array}{l}\text { Lo } \\
\text { (tiež le, ak je predmetom muž) }^{*} \\
\text { La } \\
\text { Lo }\end{array}$ & $\begin{array}{l}\text { Los } \\
\text { Las } \\
--\end{array}$ \\
\hline \multirow{2}{*}{\multicolumn{2}{|c|}{$\begin{array}{l}\text { CI } \\
\text { (nepriamy predmet) }\end{array}$}} & Le & les \\
\hline & & \multicolumn{2}{|c|}{ (alebo se pred iným neprízvučným zámenom) } \\
\hline
\end{tabular}

*V Esbozo de una nueva gramática de la lengua española (RAE, 1973) (Náčrt novej španielskej gramatiky) sa považuje za leísmo používanie le na veci, ale pripúšt’a používanie le pre osoby v mužskom rode $\mathrm{v}$ singulári, leísmo v pluráli bolo vždy podl'a RAE nespisovné, pretože jeho výskyt v najstarších textoch v kastílčine je zriedkavý. Zároveň tým môžeme vyslovit' normu, ktorá upravuje používanie týchto zámen:

Ak zámeno plní funkcu priameho predmetu, používajú sa zámená lo, los pre mužský rod (singulár aj plural) a la, las pre ženský rod (singulár aj plurál):

¿Has visto a Juan? Sí, lo vi ayer. (Videl si včera Juana? Áno, videl som ho včera.) ¿Has visto a Juan y a los niños? Sí, los he visto en el parque. (Videl si věera Juana a deti? Áno videl som ich $v$ parku.)

Compré la medicina y se la di sin que nadie me viera. (Kúpil som medicínu a dal som mu 
ju tak, aby ma nikto nevidel.)

¿Has recogido a las niñas? Sí, las recogí antes de ir al taller. (Vyzdvihol si dievčatá? Áno, vyzdvihol som ich včera pred odchodom do dielne.)

[Z dôvodu rozšíreného používania zámena le pre mužské životné mená vzdelanými hovoriacimi v určitých častiach Španielska, sa pripúšt'a pre singulár maskulína použivanie zámena le vo funkcii priameho predmetu: ¿Has visto a Jorge? Sí, le vi ayer en el parque. (Videl si Jorgeho? Áno, videl som ho v parku.)]

2. Diccionario panhispánico de dudas (Panhispánsky slovník pochybnosti):

LEÍSMO. Es el uso impropio de le(s) en función de complemento directo, en lugar de $l o$ (para el masculino singular o neutro), los (para el masculino plural) [...] Por tanto, son casos de leísmo usos como los siguientes, en los que le funciona como complemento directo: «Era Huayna Cápac, según dicen muchos indios que LE vieron y conocieron, de no muy gran cuerpo» (Salvador Ecuador [Ec. 1994]); "Los romanos [...] solían cocinarLE [el cerdo] entero» (VV. AA. Matanza [Esp. 1982]). Debido a su extensión entre hablantes cultos y escritores de prestigio, se admite el uso de le en lugar de lo en función de complemento directo cuando el referente es una persona de sexo masculino «Tu padre no era feliz. [...] Nunca LE vi alegre» (TBallester Filomeno [Esp. 1988]). Sin embargo, el uso de les por los cuando el referente es plural, aunque no carece de ejemplos literarios, no está tan extendido como cuando el referente es singular, por lo que se desaconseja en el habla culta: "Casi nunca LES vi con chicas» (Vistazo [Ec.] 3.4.97). (http://lema.rae.es/dpd/?key=leísmo)

Preklad:

LEÍSMO. Je nesprávne používanie zámen $l e(s)$ namiesto lo alebo los vo funkcii priameho predmetu (pre mužský rod v singulári a pluráli alebo pre neutrum) [...] Za leísmo sa považujú nasledujúce prípady, v ktorých le funguje ako priamy predmet: «Era Huayna Cápac, según dicen muchos indios que LE vieron y conocieron, de no muy gran cuerpo» (Salvador Ecuador [Ec. 1994]) (Huayna Cápac bol, podl'a toho, čo hovoria indiáni, ktorí HO videli a poznali ....) ; «Los romanos [...] solian cocinarLE [el cerdo] entero» (Rimania .... HO (prasa) zvykli robit' celé) (VV. AA. Matanza [Esp. 1982]).

3. Nueva gramática de la lengua española (Nová gramatika španielskeho jazyka) predstavuje širokú škálu osobných zámen, z ktorých vyberáme nasledovné:

Acusativo singular: lo (Eso no lo necesito. Nepotrebujem to.) la (Trae la carpeta y dámela. Dones tašku a daj mi ju.)

Acusativo plural: $\quad$ los (A esos ni los nombres. Tých ani nespomínaj.) las (Estas notas ya las he leído. Už si ich čítal, tie poznámky.)

Dativo singular: le (Le presté mi bicicleta. Požičal som mu/jej bicykel.)

Dativo plural: $\quad$ les (Les ofrezco mi casa. Ponúkam im môj dom.)

(Nueva gramática de la lengua española, 2010: 300) 
Čo sa týka fenoménu leísmo, Nová gramatika spomína tri typy chýb, z ktorých nás zaujíma leísmo $\mathrm{v}$ prípade mužských životných substantív:

Leísmo de persona masculino: uso del pronombre le como acusativo con sustantivos masculinos de persona: A Mario le premiaron en el colegio. (Nueva gramática de la lengua española, 2010: 315)

Preklad:

Leísmo pri mužských životných substantívach: používanie zámena le v akuzatíve pri mužských životných menách: A Mario le premiaron en el colegio. (Odmenili ho v škole.)

4. Gramática descriptiva de la lengua española (Opisná gramatika španielskeho jazyka) ponúka nasledujúcu tabul'ku:

\section{ACUSATIVO DATIVO}

1s. me

2s. te

3s. lo/la le

1p. Nos

2 p. os

3p. los/las les

(Gramática descriptiva de la lengua española 1, 2000: 1221)

O leísme sa v nej hovorí nasledovné:

La gramática normativa entiende por leísmo el uso de la forma le en lugar de lo (o excepcionalmente, $l a$ ) como pronombre para referirse al complemento directo: ¿Conoces a Juan? Sí, le conozco hace tiempo. (Gramática descriptiva de la lengua española 1, 2000: 1319)

Preklad:

Normatívna gramatika pokladá za leísmo používanie formy le namiesto lo (výnimočne la) ako zámeno pre priamy predmet: ¿Conoces a Juan? Sí, le conozco hace tiempo. (Poznáš Juana? Áno poznám ho už dlho.)

Analyzovali sme štyri normatívne gramatiky, z ktorých dve (DRAE a DPD de la RAE) pripúšt’ajú používanie zámena le pre podstatné mená životné mužského rodu, hoci odporúčajú použivat' zámeno lo. Nueva gramática a Gramática descriptiva považujú za leísmo používanie zámena le pre mužské životné substantíva v akuzatíve. Ani jedna z analyzovaných gramatík nepripúšsta použivanie les pre mužské substantíva $\mathrm{v}$ akuzatíve plurálu. $Z$ uvedeného vyplýva, že môžeme používanie zámen $\mathrm{v}$ akuzatíve a datíve $\mathrm{v}$ španielčine zjednodušit nasledovne:

\section{akuzatív: lo, la, los, las \\ datív: le, les}


Je však treba pripomenút', že ešte vždy sa môžeme stretnút' s používaním zámena le v akuzatíve, predovšetkým v určitých častiach Španielska (v Latinskej Amerike sa leísmo takmer nevyskytuje) a tiež v mnohých učebniciach španielčiny.

\section{Interferencie a problémové slovesá}

Ked' už vieme správne používat' zámená le pre CI (nepriamy predmet) a lo, la pre $\mathrm{CD}$ (priamy predmet), je potrebné vediet' rozlíšit datív a akuzatív vo vete. Spomínali sme, že obyčajne sa CI zhoduje so slovenským datívom a CD s akuzatívom, napríklad:

$$
\begin{array}{ll}
\mathrm{CI}=\text { datív: } & \text { le explico }=\text { jemu/jej vysvetlujem } \\
& \text { le compro }=\text { jemu/jej kupujem } \\
& \text { les doy }=\text { im dávame } \\
\mathrm{CD}=\text { akuzatív: } & \text { lo/la veo }=\text { jeho/ju vidím } \\
& \text { lo compro }=\text { to kupujem } \\
& \text { los/las espero }=\text { ich čakám }
\end{array}
$$

Nie vždy sa však tieto kategórie v slovenčine a španielične zhodujú. Medzi najpoužívanejšie slovesá, ktoré sú $\mathrm{v}$ slovenčine $\mathrm{v}$ datíve a $\mathrm{v}$ španielčine $\mathrm{v}$ akuzatíve patria slovesá doler, interesar, robar:

le duele $(C I) \rightarrow$ juljeho boli (akuzativ)

le interesa (CI) $\rightarrow$ ju/jeho zaujima (akuzativ)

le robaron $(C I) \rightarrow$ ju/jeho okradli (akuzativ)

A naopak, slovesá, ktoré sú $\mathrm{v}$ španielčine $\mathrm{v}$ akuzatíve a v slovenčine v datíve:

lo/la llama $(C D) \rightarrow$ jej/jemu volá (dativ) ${ }^{3}$

lo/la ayuda $(C D) \rightarrow$ jej/jemu pomáha (dativ)

Je viac slovies, ktoré môžu byt' problematické pri používaní zámen v datíve alebo akuzatíve, pretože sa môžu bud' viazat' s obidvoma pádmi, pričom menia alebo modifikujú význam alebo sa viažu s rozdielnymi pádmi v každom jazyku. Táto väzba závisí od viacerých faktorov, akými sú napr. subkategoriálne črty (životnost', rod, atd'.):

\section{ŠPANIELČINA}

informar a alguien de algo $(\mathrm{A}) \rightarrow$

La informaron de la presencia...

informar algo a alguien (D) $\rightarrow$

Le informaron que...

avisar a alguien de algo (A) $\rightarrow$

La avisaron del peligro.

\section{SLOVENČINA}

Informovali ju o pritomnosti... (A)

Oznámili jej, že .... (D)

Oboznámili ju o nebezpečenstve (A)/

Oznámili jej nebezpečenstvo (D)

\footnotetext{
3 V niektorých oblastiach Španielska alebo Latinskej Ameriky sa používa sloveso llamar (telefonovat') s datívom le llamo, hoci tento úzus ešte nie je akceptovaný akadémiou.
} 
avisar algo a alguien (D) $\rightarrow$

Le avisaron que...

Oznámili jej, že ... (D)

molestar, cansar, asustar, afectar,

divertir + životné $(\mathrm{A}) \rightarrow$

La molestó (el señor a mi hija).

Obt’ažoval/ unavil/vyl'akal ju. (A)

molestar, cansar, asustar + neživotné $(\mathrm{D}) \rightarrow$

Le molestó el ruido (a mi hija).

Vadil jej hluk. (D) Unavil ju hluk. (A)

besar, pinchar, acariciar + životné $(\mathrm{A}) \rightarrow$

La besó (a Alicia) en la frente.

Vyl'akal ju hluk. (A)

besar, pinchar, acariciar, lavar + neživotné $(\mathrm{D}) \rightarrow$ Le besó (a Alicia) la cara.

Pobozkal/ popichal/

pohladkal ju po/na čele. (A)

esperar + životné $(\mathrm{A}) \rightarrow$

La estuve esperando (a mi amiga).

Pobozkal/ popichal/ pohladkal/

umyl jej tvár. (D)

Čakala som ju. (A)

esperar + neživotné $(\mathrm{D}) \rightarrow$

Le espera una noche larga (a mi amiga).

Čaká ju dlhá noc. (A)

comprender, entender $(\mathrm{A}) \rightarrow$

No la comprendo (a mi prima) por qué lo hace.

Nechápem ju. (A)

comprender, entender algo a alguien (D) $\rightarrow$

No le comprendo (a mi prima) lo que dice.

Nerozumiem jej, čo hovorí. (D)

robar a alguien $(\mathrm{A}) \rightarrow A$ mi hija me la robaron.

Ukradli mi ju, moju dcéru. (A)

robar algo a alguien (D) $\rightarrow$

A mi madre le robaron el bolso.

A mi madre le robaron. $\rightarrow$ neprechodné

Ukradli jej kabelku. (D)

Okradli ju. (A) $\rightarrow$ prechodné abrir $(\mathrm{A}) \rightarrow$

A mi madre la abrieron (operaron).

Otvorili ju (operovali). (A)

abrir algo a alguien (D) $\rightarrow$

A mi madre le abrieron la puerta.

Otvorili jej dvere. (D)

tirar (A) $\rightarrow$ A mi madre la tiraron al suelo.

Hodili ju na zem. (A)

tirar (D /disparar/) $\rightarrow$

A mi madre le tiraron por la espalda.

Strelili jej do chrbta. (D)

dejar $(\mathrm{A}) \rightarrow$ No la dejé salir a mi hija.

Nenechal som ju ist'von. (A)

Nedovolil som jej. (D)

dejar (D) $\rightarrow$ No le dejé el coche.

Nepožičal som jej auto. (D) 
mentir (D) $\rightarrow$ No le mientas a tu profesora.

engañar $(\mathrm{A}) \rightarrow$ No la engañes a tu profesora.

tomar el pelo (D) $\rightarrow$ Le tomaron el pelo.

prender el fuego (D) $\rightarrow$ Le prendieron el fuego.

echar un vistazo (D) $\rightarrow$ Le echo un vistazo.

sacar el brillo a algo (D) $\rightarrow$

Le he sacado brillo al mueble.

hacer añicos/hacer polvo (A) $\rightarrow$

Tiró el jarrón y lo hizo añicos.

pegar $(\mathrm{D} /$ dar golpe/) $\rightarrow$ Le pegó una paliza

pegar a alguien $(\mathrm{A}) \rightarrow$ La pegaba mucho.

saludar a alguien $(\mathrm{A}) \rightarrow$ La saluda y le dice...

saludar (D zdvorilostné) $\rightarrow$

Le saluda atentamente...

pedir algo (A) $\rightarrow$ La pedí (una transferencia).

pedirle algo a alguien $(\mathrm{D}) \rightarrow$ Le pedí que viniera.

encantar a alguien (A/emocionar/) $\rightarrow$

Todo la encantaba.

encantar a alguien (D /gustar/) $\rightarrow$

Le encantan los libros.

tener manía a algo/alguien (D) $\rightarrow$

Le tengo manía a esa chica.

tener a alguien $(\mathrm{A}) \rightarrow$

La tengo en casa con fiebre.

tocar algo (A) $\rightarrow$ Toca la guitarra

tocar algo a alguien (D) $\rightarrow$

Le ha tocado la lotería.

Le ha tocado la cara.

La tocó.
Neklam jej. (D); Neklam ju. (A)

Neklam ju. (A)

VYSTRELILI SI Z NEJ. (G)

Zapálili ju. (A)

Mrknem sa na ňu. (A)

Vyleštila som ho. (A)

Rozbil ho na kúsky.(A)

Dal jej nakladačku.(CI); Zbil ju. (CD)

Bijával ju vel’a. (A)

Zdraví ju. (A)

Zdraví vás. (A)

Žiadal som o ňu.(A)

Požiadal som ju, aby prišla. (A)

Všetko ju nadchýnalo/očarúvalo. (CD)

Páčia sa jej knihy. (D)

Nadchýnajú ju knihy.(A)

Nemám ju rada. (A)

Mám ju doma s horúčkou. (A)

HRÁ NA GITARE. (L)

ONA VYHRALA V LOTÉRII. (N)

DOTKOL SA JEJ TVÁRE. (G)

DOTKOL SA JEJ. (G) 
Neosobné slovesá so se $(\mathrm{D} / \mathrm{mužský/)} \rightarrow$

Se le considera el mejor actor.

Neosobné slovesá so se (A/ženský/) $\rightarrow$ Se la considera la mejor actriz.

\section{Považujú ho za najlepšieho herca. (A)}

Považujú ju za najlepšiu herečku. (A)

Nie je jednoduché vyvodit' jednoduchý záver alebo jasné pravidlo na používanie zámen $\mathrm{v}$ datíve alebo akuzatíve $\mathrm{v}$ španielčine. Uvedené príklady v tabul'ke sme rozlíšili nasledovne: hrubo zdôraznené sú prípady, ked' je v jednom jazyku použitý datív a v druhom akuzatív alebo naopak, a kapitálkami sú príklady, ked' je v slovenčine použitý iný pád ako datív alebo akuzatív. V tabul'ke sme mohli vidiet', že používanie datívu alebo akuzatívu závisí od toho, či viazaný predmet je životný alebo neživotný (molestar, afectar, asustar, ofender, perjudicar, esperar, besar, acariciar), mužského alebo ženského rodu (neosobné slovesá), či je sloveso viacvýznamové (tener, pegar, tirar, abrir, tocar, encantar, dejar), prechodné (robar, entender), či vyjadruje zdvorilost' (saludar), či je čast'ou ustálenej konštrukcie (prender el fuego, sacar el brillo, hacer añicos, tomar el pelo), atd'.

Čo sa týka ekvivalencií v slovenčine, používanie datívu alebo akuzatívu závisí mnohokrát od toho, ako sloveso preložíme alebo od toho, či má španielske sloveso dva ekvivalenty v slovenčine, kde jeden viaže akuzatív a druhy datív (ukradnút' okradnút', oznámit' - informovat', nechat'-dovolit'). Sú slovesá, ktoré sa viažu v slovenčine naopak ako v španielčine (doler, llamar, molestar, asustar), slovesá, ktoré môžu viazat' obidva pády (klamat' niekomu/ niekoho), ustálené výrazy, ktoré sa prekladajú odlišne (prender el fuego, tomar el pelo), slovesá, ktoré viažu iné pády ako akuzatív a datív (dotknút' sa, vyhrat', hrat' na niečom) a v slovenčine neexistujú slovesá, ktoré rozlišujú medzi ženským a mužským rodom substantíva na používanie datívu alebo akuzatívu.

\section{Záver}

Našu analýzu môžeme na záver zhrnút' do nasledujúcich bodov:

1. Uprednostňuje sa používanie le pre CI (datív) a forma lo pre CD (akuzatív).

2. Vo všeobecnosti sa zhoduje španielsky CI so slovenským datívom a španielsky CD so slovenským akuzatívom.

3. Existujú slovesá, ktoré sa v španielčine viažu s datívom a v slovenčine $\mathrm{s}$ akuzatívom alebo naopak (doler, interesar, robar, llamar, ayudar). Pri týchto slovesách dochádza $\mathrm{k}$ interferenciám.

4. Existujú slovesá v španielčine, ktoré sa viažu aj s datívom aj s akuzatívom v závislosti od viacerých faktorov (životné/neživotné substantívum, substantívum v ženskom/mužskom rode, sloveso prechodné/neprechodné, polysémantické, neosobné, sloveso ako súčast' ustálenej konštrukcie alebo zdvorilostnej formulky).

5. Slovesá, ktoré môžu spôsobovat' váhanie v španielčine, môžu v slovenčine bud' viazat' predmet v tom istom páde ako v španieličine (informovat' ju, oznámit' 
jej, pobozkat' ju, pobozkat' jej čelo) alebo sa môžu preložit' takým spôsobom, aby viazali predmet v rovnakom páde (klamat' jej - klamat' ju, ukradnút' jej-okradnút ju, páčit'sa jej-nadchýnat' ju, oznámit' jej-oboznámit' ju, vadil jej-unavil ju, nerozumiem jej-nechápem ju, zbil ju - dal jej nakladačku, dovolit' jejnechat' ju) alebo viažu predmet $\mathrm{v}$ opačnom páde (le asusta - l'aká ju, le espera una noche - čaká ju noc, prenderle el fuego - zapálit' ju, echarle un vistazo mrknút' sa na ňu, sacarle el brillo - vyleštit' ju, pedirle que venga-požiadat' ju, tenerle manía - nemat' ju rada, se le considera - považujú ho).

6. Sú slovesá, ktoré v slovenčine viažu iný pád ako akuzatív alebo datív (tomarle el pelo - vystrelit' si z nej, tocar algo - hrat' na niečom, tocarle en la lotería - vyhrat'v lotérii, tocarle - dotknút' sa jej).

7. Chyby, ktorých sa dopúšt’ajú slovensky hovoriaci vyplývajú z vyššie uvedených dôvodov, napríklad:

a. Používanie les pre životný akuzatív plurálu zapríčinené analógiou v singulári (le veo - les veo*).

b. Používanie le pre akuzatív v ženskom rode pod vplyvom používania le $\mathrm{v}$ datíve pre všetky rody (les espero* a las chicas).

c. Rozlišovanie $l e, l a \mathrm{v}$ datíve kvôli rozlišovaniu rodu $\mathrm{v}$ akuzatíve a tým chybné používanie la $\mathrm{v}$ datíve CI (la* digo).

d. Chybné používanie zámen v datíve pre akuzatív a naopak pri určitých slovesách kvôli interferenciám zo slovenčiny (doler, llamar, ayudar, pedir, etc.) alebo kvôli ambivalentným španielskym slovesám, ktoré môžu viazat' aj datív aj akuzatív v závisloti od faktorov spomínaných vyššie.

\section{Referencias bibliográficas}

ALARCOS LLORACH, E. (2006): Gramática de la lengua española, RAE Espasa Calpe, Madrid.

ALONSO RAYA, R. (2005): Gramática básica del estudiante de español, Difusión, Barcelona.

AUROVÁ, M. (2007): „Construcciones impersonales españolas en el lenguaje jurídico-administrativo“. In: Hokrová, Z., Machurková, K. et al. (eds.), Profilingua 2007. Sbornik př́spěvků z konference, Západočeská univerzita v Plzni, pp. 456-465.

BAJZÍKOVÁ, E., ORAVEC J., FURDÍK, J. (1984): Súčasný slovenský jazyk. Morfológia, SPN, Bratislava.

BAJZÍKOVÁ, E., ORAVEC, J. (1986): Súčasný spisovný slovenský jazyk. Syntax, SPN, Bratislava.

BOSQUE MUÑOZ, I., DEMONTE BARRETO, V. (2000): Gramática descriptiva de la lengua española, RAE - Espasa Calpe, Madrid.

BORREGO NIETO, J., DI TULLIO, A. (2010): Nueva gramática de la lengua española, RAE - Espasa Libros, Madrid. 
CERROLAZA GILI, Ó. (2011): Diccionario práctico de gramática, Edelsa, Madrid. CANO VARELA, D. P. (2001): „Algunas observaciones sobre el espaňol de Colombia“. In: III Coloquio Internacional. Tendencias y posibilidades de la hispanística actual, AnaPress, Bratislava, pp. 169-176.

DPD (2005): Diccionario panhispánico de dudas. $\mathrm{http}: / / \mathrm{www} \cdot$ rae.es/recursos/diccionarios/dpd

DRAE (2014): Diccionario de la lengua española, $23^{\text {a }}$ edición. $\mathrm{http}: / /$ www.rae.es/recursos/diccionarios/drae

GÓMEZ TORREGO, L. (2011): Análisis morfológico. Teoría y práctica, Ediciones SM, Madrid.

GÓMEZ TORREGO, L. (2009): Hablar y escribir correctamente II. Gramática normativa del español actual, Arco/Libros, Madrid.

GÓMEZ TORREGO, L. (2011): Gramática didáctica del español, Ediciones SM, Madrid.

GÓMEZ-PABLOS, B. (2002): „El español neutro: problemas y soluciones“. In: Sánchez Corrales, V. M. (ed.), Actas del XIII Congreso ALFAL 18-23 de febrero 2002, San José de Costa Rica (CD-rom).

HERNÁNDEZ ALONSO, C. (1973): Gramática funcional del español, Gredos, Madrid.

KRAJČOVIČ, R. (1988): Vývin slovenského jazyka a dialektológia, SPN, Bratislava.

MATTE BON, F. (2006): Gramática comunicativa del español, Edelsa, Madrid.

MISTRÍK, J. (1988): Moderná slovenčina, SPN, Bratislava.

PAULINY, E. (1981): Slovenská gramatika, SPN, Bratislava.

PAVLOVIČ, J. (2012): Syntax slovenského jazyka I. http://pdf.truni.sk/e-ucebnice/pavlovic/syntax-1

SECO, M. (2004): Gramática esencial del español, Espasa Calpe., Madrid. 